\title{
Personalistyczne postrzeganie małżeństwa i rodziny profilakłyka współczesnych niebezpieczeństw zagrażających rodzinie
}

\author{
Personalist approach towards marriage and family \\ as a means of preventing modern threats against family
}

\begin{abstract}
Personalism is a philosophical school of thought focused on thorough considerations around the human being. A few types and branches of personalism can be distinguished, for example by country of origin and development of thought, or by the analysis of different elements that constitute a human being. On Polish ground, it is the teaching of St. John Paul II that deserves particular attention. On the basis of a specific view on human beings in their integral and social dimension, personalism formulates a characteristic vision of marriage and family. It emphasizes the understanding of family as a community of people, it teaches of the specificity of a relationship between a man and a woman, which leads to a tradition-
\end{abstract}

al way of defining marriage and family. Consideration of biological, psychological and spiritual dimensions of the functioning of a human being triggers a complex approach towards family. This means that it is the basis for determining rules of psychological and spiritual establishment of marriage and family bonds. It also concerns the way of raising children, at the same time becoming a special place for personal upbringing. Reminding and promoting the abovementioned understanding of family can be a means of preventing threats of the modern world. This means that it can prevent the destruction of a family, as well as any attempts to redefine marriage and family - present in current social reality. It can influence the process 
of supporting marriage and family with regard to appropriate communication, dealing with marriage crisis and with upbringing children. The way to perform those preventive and supporting actions should first of all be the period of preparation for marriage, in a broad and direct aspect. Apart from that, including it in the constant formation of families may constitute a specific form of protection.

Keywords: personalism, family, prophylaxis

We współczesnym świecie pojawia się wiele nowych wizji małżeństwa i rodziny. Występują zwłaszcza takie, które dążą do przedefiniowania tradycyjnego modelu małżeństwa. Sobór Watykański II w Konstytucji duszpasterskiej o Kościele w świecie współczesnym Gaudium et spes nakreślając sytuację rodziny stwierdza, że: „Nie wszędzie godność tej instytucji jednakim świeci blaskiem, gdyż przyćmiewa ją wielożeństwo, plaga rozwodów, tzw. wolna miłość i inne zniekształcenia. Ponadto miłość małżeńska bardzo często doznaje sprofanowania przez egoizm, hedonizm i niedozwolone zabiegi przeciw poczęciu. Poza tym dzisiejsze warunki gospodarcze, społeczno-psychologiczne i polityczne wprowadzają w rodzinę niemałe zaburzenia"1.

W odpowiedzi na wskazane wyżej zagrożenia wydaje się konieczne ukazywanie i przypominanie o wartości małżeństwa i rodziny widzianej z perspektywy personalizmu. Bowiem pogląd na temat tych instytucji oraz wartości, na których są budowane, mają charakter kluczowy w sposobie ich przeżywania. Konkretne postulaty, na jakie wskazuje owa perspektywa, zostaną tu ukazane jako czynniki zapobiegające uleganiu niebezpieczeństwom zagrażającym rodzinie.

W niniejszym opracowaniu zacznie się od ukazania ogólnych założeń personalizmu. Następnie scharakteryzowana zostanie osoba ludzka w jej indywidualnym i społecznym wymiarze. Potem, przechodząc do sedna tematu, szczególną uwagę poświęci się specyficznemu wątkowi owego nauczania, jakim jest ujmowanie wspólnoty małżeńskiej jako communio personarum. Na zakończenie ukazany zostanie praktyczny wymiar życia małżonków według tych postulatów oraz propagowania takiej wizji. Umieszczony on zostanie w kontekście profilaktyki dla wybranych współczesnych zagrożeń stojących przed rodziną. Dodatkowo, celem niniejszej pracy jest ukazanie communio personarum jako stylu życia uniwersalnego, nie zaś ideału nieosiągalnego dla ogółu małżeństw. 


\section{Personalizm - charakterystyka ogólna}

Personalizm to kierunek filozoficzny, którego głównym obszarem badań jest człowiek określany jako „osoba”. Za tym pojęciem kryją się określone cechy charakterystyczne, zwłaszcza zaś szczególna i niepodważalna godność osoby². Sama nazwa personalizmu wywodzi się od łacińskiego słowa persona oznaczającego osobę. Jednak pierwotna etymologia tego słowa odnosiła się do innego znaczenia - terminu phersu, który oznaczał aktora w masce, odgrywającego rolę na scenie. Podobnie, znaczenie terminu personalizm nie wiązało się wprost z jego dzisiejszym rozumieniem. We Francji w 1737 roku, kiedy użyto go pierwszy raz, służył on do określenia indywidualizmu oraz egocentryzmu. Następnie, w Niemczech, posługiwano się nim w odniesieniu do Boga osobowego $^{3}$. To ostatnie powiązanie terminologiczne jest ściśle związane z zasadniczym źródłem dzisiejszego rozumienia personalizmu - nauki o Trójcy Świętej mającej jedną naturę w trzech osobach ${ }^{4}$.

Zasadniczo, jest to kierunek złożony i różnorodny, ponieważ występuje na gruncie wielu nauk oraz wyróżnia się wiele jego odmian ${ }^{5}$. Każda z nich, ma odmienny zakres pojęciowy - odnosi się do innych składników osoby ludzkiej. Z kolei typ personalizmu wyznacza światopogląd jego prekursora (np. personalizm tomistyczny oparty na poglądach św. Tomasza z Akwinu), rodzaj szerszego kierunku myślowego, w którego skład wchodzi personalizm (np. personalizm chrześcijański) lub kraj pochodzenia i rozwoju myśli. W Polsce czołowymi przedstawicielami personalizmu byli Albert Krąpiec oraz Karol Wojtyła, którzy wpłynęli na rozwój myśli personalistycznej na Katolickim Uniwersytecie Lubelskim. Karol Wojtyła rozwijał swą myśl personalistyczną jako papież $\dot{ }^{6}$ Samo zaś personalistyczne tło w nauczaniu Kościoła katolickiego obejmuje jeszcze wcześniejszy okres - co najmniej od pontyfikatu Pawła VI i Soboru Watykańskiego II ${ }^{7}$.

„Obecnie personalizm występuje w co najmniej dwóch podstawowych wariantach, tzn. jako personologia, czyli dział antropologii ukazujący człowieka jako «osobę», ale w sposób węższy - jako element szerszego kierunku. Po dru-

2 Por. P. Pawłowska, Kobiecość: wizja genderowa a perspektywa personalistyczna listu apostolskiego „Mulieris dignitatem”, (praca magisterska), Katowice 2014, s. 27.

3 Por. C. S. Bartnik, Szkice do systemu personalizmu, Lublin 2006, s. 41, za: P. Pawłowska, Kobiecość: wizja..., dz. cyt., s. 27.

4 Por. C. S. Bartnik, Personalizm, Lublin 2013, s. 75-76.

5 Por. S. Kowalczyk, Personalizm - podstawy, idee, konsekwencje, Lublin 2012, s. 24.

6 Por. I. Dec, Personalizm, [w:] Powszechna encyklopedia filozofii, t. 8, red. A. Maryniarczyk, Lublin 2007, s. 122-126.

7 Por. A. Pastwa, Istotne elementy małżeństwa. W nurcie odnowy personalistycznej, Katowice 2007, s. 65. 
gie, personalizm postrzegany jako system, w którym osoba ludzka stanowi centralny obszar zainteresowań i punkt wyjścia dla innych analiz”" Co więcej, „systemowe ujęcie tworzy wizję całej rzeczywistości, w której «fenomen osoby ludzkiej» jest punktem odniesienia, fundamentem i pozycją stałą, na której i wobec której analizuje się różne obszary otoczenia. W takim rozumieniu personalizm mógłby być podstawą innych kierunków myślowych - węższych lub szerszych"”. W niniejszym opracowaniu systemowy personalizm został przyjęty jako kierunek stanowiącego fundament przekonań na temat małżeństwa i rodziny.

\section{Osoba ludzka i jej godność}

W pierwszej kolejności należy przywołać wizję człowieka jako jedności cielesno-psychiczno-duchowej. Jest to tak głęboka jedność wszystkich tych sfer, że człowieka nazwać można «duchem ucieleśnionym»» ${ }^{10}$ Co więcej, znaczy to, że „dzięki duszy duchowej ciało utworzone z materii jest ciałem żywym i ludzkim; duch i materia w człowieku nie są dwiema połączonymi naturami, ale ich zjednoczenie tworzy jedną naturę"11. Do objaśnienia każdej z tych sfer wykorzystuje się dorobki innych nauk - biologii, medycyny, psychologii i teologii.

Personalizm ukazuje całe bogactwo osoby ludzkiej. Koncentruje się na charakteryzowaniu jej poprzez ukazywanie dwóch wymiarów, w których funkcjonuje - indywidualnym i społecznym. Skupiając się w pierwszej kolejności na wymiarze indywidualnym, podkreśla się zbiór atrybutów osoby ludzkiej. Atrybuty te mają charakter filozoficzny, dlatego dla celów tej pracy nie jest istotne opisywanie tu każdego z nich. Warto jedynie wskazać, że chodzi o: substancjalność, samoistność, podmiotowość, osobowość, jaźń. Na tej podstawie można zasadniczo stwierdzić, że osoba (odnosząc się do znaczenia wyszczególnionych cech) jest bytem konkretnym i określonym; rzeczywistym i realnym; jest «kimś», a nie «Czymś»; ma swój sposób bycia oraz duchowy wymiar ${ }^{12}$. Następnie istotne jest wskazanie na definicję osoby ludzkiej, która - jak podkreśla Czesław Bartnik nigdy nie będzie wyczerpująca ze względu na złożoność owej kategorii. Mimo to można w ogólności stwierdzić, że osoba jest „subsystencją rozumianą jako realna «substancja indywidualna», mającą własne istnienie, odrębność, swoje s. $27-28$.

C. S. Bartnik, Szkice..., dz. cyt., s. 41, za: P. Pawłowska, Kobiecość: wizja..., dz. cyt.,

C. S. Bartnik, Personalizm..., dz. cyt., s. 19-20, za: tamże.

Por. FC 11.

KKK 365.

12 Por. C. S. Bartnik, Personalizm..., s. 176-184. 
własności, bytującą jako «ktoś», co jest przeciwne istnieniu jako «coś» - charakterystycznego dla świata rzeczy. Ważne jest, że subsystencja ta jest zespolona z bytem »ja», czyli jaźnią duchową"13.

Szczególnym przymiotem wyróżniającym osobę ludzką na tle innych stworzeń jest jej godność. Niezwykle ważne jej znaczenie ukazywał m.in. św. Jan Paweł II, który przekonywał, że „każdej istocie ludzkiej, od poczęcia aż po naturalną śmierć, należy się godność osoby" ${ }^{14}$. Rozważania nad postrzeganiem osoby ludzkiej przez pryzmat jej godności należy zacząć od wskazania jej źródła. Z teologicznego punktu widzenia najdoskonalszą genezę godności osoby ludzkiej ukazuje biblijny tekst z Księgi Rodzaju o pierwszym opisie stworzenia świata ${ }^{15}$. Po opisie stworzenia nieba i ziemi, dnia i nocy, roślinności, słońca i księżyca, zwierząt, następuje szczytowy moment stworzenia świata - szczególnie ważny dla niniejszych rozważań. Dzieje się to dnia szóstego, kiedy Bóg stwierdza „ «Uczyńmy człowieka na Nasz obraz, podobnego Nam. Niech panuje nad rybami morskimi, nad ptactwem powietrznym, nad bydłem, nad ziemią i nad wszystkimi zwierzętami pełzającymi po ziemi!» Stworzył więc Bóg człowieka na swój obraz, na obraz Boży go stworzył: stworzył mężczyznę i niewiastę"16. Z tego fragmentu wynika, że człowiek jest szczytem Bożego stworzenia. Jak tłumaczy św. Jan Paweł II, opis ten podaje wyraźną gradację - „człowiek nie powstaje w zwykłej kolejności, ale Stwórca niejako zatrzymuje się przed powołaniem go do istnienia, jakby wchodził w siebie, gdy podejmuje decyzję"17. Następnie ową prawdę tłumaczy twierdząc, że: „człowiek jest szczytem całego stworzenia w świecie widzialnym; rodzaj ludzki, który bierze początek w powołaniu do istnienia mężczyzny i kobiety, wieńczy całe dzieło stworzenia"18. Kolejnym powodem przypisywania człowiekowi szczególnej godności jest fakt stworzenia człowieka na obraz i podobieństwo Boże. „Człowiek ukazywany jest jako jedyne stworzenie, które zostało powołane do poznania swego Stwórcy, do uczestniczenia w życiu Bożym i do trwania w przymierzu z Nim. Szczególnym nadprzyrodzonym - znakiem podobieństwa człowieka do Boga jest posiadanie duszy, dzięki której człowiek kieruje swoje cele i życie w kierunku Boga, ma możliwość otwarcia się na łaskę Bożą oraz ma zdolność przyjmowania miłości i obecności Bożej. Podobieństwo do Boga wyraża się także przez fakt natural-

\footnotetext{
13 C. S. Bartnik, Szkice do systemu..., s. 43-44, za: P. Pawłowska, Kobiecość: wizja...,

14 Kongregacja Nauki Wiary, Instrukcja Dignitas personae dotycząca niektórych problemów bioetycznych, 1 .

15 Por. Rdz 1, 1-25; por. MD 6.

16 Rdz 1, 26n.

17 Jan Paweł II, Mę̇̇zzyzną i niewiastą stworzył ich, Watykan 1986, s. 9-10.

18 MD 6.
} s. 31 . 
nych przymiotów człowieka: posiadania wolnej woli, rozumu"19. Nie bez znaczenia dla niniejszych rozważań jest fakt stworzenia mężczyzny i niewiasty wskazujący na celowe, płciowe różnicowanie osoby ludzkiej. Równocześnie obie płcie w równym stopniu stworzone są na obraz i podobieństwo Boże ${ }^{20}$.

\section{Społeczny wymiar byłowania - osoba ludzka jako dar}

„Oczywiste jest, że człowiek od zawsze przebywał w grupach społecznych. Równie niezaprzeczalne jest, że owe grupy oraz indywidualne osoby oddziałują na siebie nawzajem”21. „Dlatego można powiedzieć, że sama istota osoby ma strukturę społeczną, tj. nastawioną ku innym"22. W perspektywie teologicznej relacyjny charakter osoby ludzkiej widoczny jest już w przytoczonym wyżej fragmencie z Księgi Rodzaju, gdzie autor natchniony, przywołując słowa Pana Boga, posługuje się liczbą mnogą („Uczyńmy człowieka na Nasz obraz"23). Jest to dwoisty podmiot Boga, który stwarzając człowieka na swój obraz i podobieństwo, stwarza go podobnym także w tym zakresie - spo$ł_{\text {łecznym }}^{24}$. Znamienny jest także fakt wynikający z drugiego opisu stworzenia świata, w którym mężczyzna po stworzeniu kobiety wypowiada słowa: „ «Ta dopiero jest kością z moich kości i ciałem z mego ciała! Ta będzie się zwała niewiastą, bo ta z mężczyzny została wzięta». Dlatego to mężczyzna opuszcza ojca swego i matkę swoją i łączy się ze swą żoną tak ściśle, że stają się jednym ciałem” (Rdz 1,23n). Człowiek - mężczyzna - doświadczając pierwotnej samotności, kiedy wśród innych stworzeń nie znajduje równego sobie partnera, podmiot właściwy do nawiązania relacji odnajduje w kobiecie, co doprowadziło do ich trwania w pierwotnej jedności ${ }^{25}$. Chociaż jedność ta została zerwana przez grzech pierworodny, to małżonkowie uzdalniani są przez ła-

19 M. Kaszowski, Obraz i podobieństwo Boże w człowieku, [w:] http://www.teologia. pl/m_k/zag03-04.html (20.06.2015r.), za: P. Pawłowska, Kobiecość: wizja..., dz. cyt., s. 37.

20 Por. MD 6.

21 W. Granat, Osoba ludzka. Próba definicji, Lublin 2006, s. 222, za: P. Pawłowska, Kobiecość: wizja..., dz. cyt., s. 34.

22 Tamże, s. 34-35.

$23 \operatorname{Rdz} 1,26$.

24 Por. E. Ozorowski, Obraz Boży, [w:] Człowiek, osoba, płeć, red. M. Wójcik, Łomianki 1998, s. 24.

25 Por. Jan Paweł II, Znaczenie pierwotnej samotności. Katecheza podczas audiencji ogólnej, 10.10.1979; Znaczenie pierwotnej jedności mężczyzny i kobiety. Katecheza podczas audiencji ogólnej, 7.11.1979, za: K. Lubowicki, Duchowość małżenska w nauczaniu Jana Pawła II, Kraków 2012, s. 276. 
skę Jezusa do urzeczywistniania i odnawiania owej komunii ${ }^{26}$. Na tym tle widoczne jest, że mężczyzna i kobieta odnajdują w sobie nawzajem odpowiednich parterów życiowych.

Istotny dla owych rozważań jest także fragment z Gaudium et spes, w którym napisane jest, że zachodzi podobieństwo „między jednością osób boskich a jednością synów Bożych zespolonych w prawdzie i miłości. To podobieństwo ukazuje, że człowiek będąc jedynym na ziemi stworzeniem, którego Bóg chciał dla niego samego, nie może odnaleźć się w pełni inaczej jak tylko poprzez bezinteresowny dar z siebie samego" ${ }^{27}$. Oznacza to w pierwszej kolejności, że podobieństwo człowieka do Boga odnosi się do przymiotu Boga związanego z jednością Trzech Osób Boskich. Dlatego owo podobieństwo oznacza także podobieństwo w „uzdolnieniu do wspólnoty z innymi osobami”28. Z kolei czynienie $\mathrm{z}$ siebie bezinteresownego daru w relacji z drugą osobą, nakierowuje na głęboko duchowe znaczenie relacji, a realizować może się we wspólnocie rozumianej jako communio ${ }^{29}$.

\section{Małżeńska communio personarum}

Karol Wojtyła, wprowadzając pojęcie communio personarum, traktował je zachęcając do tego innych - jako klucz do postrzegania małżeństwa i rodziny. Znaczenie tego pojęcia ma głębszy wymiar aniżeli socjologiczne terminy „najmniejsza komórka społeczna”, „społeczność”. To znaczy, że stwierdzenie, iż człowiek jest istotą społeczną, nie jest tym samym co powołanie do życia we wspólnocie rozumianej jako communio. Nie są to oczywiście pojęcia przeciwstawne, ale to drugie posiada o wiele głębsze znaczenie. Wskazuje na bardziej osobowy charakter relacji międzyludzkich ${ }^{30}$. W późniejszych latach Wojtyła już jako papież Jan Paweł II zwracał uwagę, że „człowiekowi nie wystarczają relacje czysto funkcjonalne, lecz potrzebuje więzi międzyosobowych, sięgających głęboko do jego wnętrza, wyrażających całkowicie bezinteresowny dar z siebie" ${ }^{31}$. Stąd mowa tu o takiej komunii osób, która opiera się na głębokich

\footnotetext{
26 Por. FC 13.

27 KDK 24.

28 K. Wojtyła, Rodzina jako „communio personarum”. Próba interpretacji teologicznej, „Ateneum Kapłańskie” 66 (1974) t. 83, z. 3, s. 350.

29 Por. tamże, s. 351.

30 Por. K. Wojtyła, Rodzina jako..., dz. cyt., s. 351-352.

31 Por. Jan Paweł II, Małżeństwo i rodzina we wspólnocie Kościoła. Homilia podczas Mszy z okazji Jubileuszu Rodzin, 15.10.2000, za: K. Lubowicki, Duchowość małżeńska..., dz. cyt., s. 275.
} 
więzach międzyosobowych. Te z kolei budowane są na personalistycznej koncepcji osoby ludzkiej, w której godność człowieka jest szczególnie ceniona ${ }^{32}$.

Communio personarum, tj. komunia osób, wyraża się w całkowitej jedności małżonków - jedności ciał, ducha i duszy ${ }^{33}$. Uwzględniając integralną koncepcję osoby ludzkiej, widzianej jako głęboka jedność cielesno-psychiczno-duchową ${ }^{34}$, wnioskuje się, że komunia osobowa, a także miłość małżonków powinna obejmować każdy wymiar funkcjonowania drugiej osoby - jej ciało, psychikę i duszę $e^{35}$. Z tego względu istotą communio personarum jest całkowite oddanie się sobie małżonków polegające na komunii ciał, charakterów, serc, umysłów, dążeń. Chodzi o takie zjednoczenie kobiety i mężczyzny, w którym pomimo słabości oddają się sobie całkowicie i wzajemnie ${ }^{36}$. Jest to zatem styl życia małżonków, w którym „bytując i działając we wzajemnym do siebie odniesieniu, przez to działanie i bytowanie wzajemnie siebie jako osoby potwierdzają i afirmują" ${ }^{37}$. Osoby przyjmują siebie ze wszystkim, co je charakteryzuje. Ważne jest, aby komunia ta wyrażała się w codzienności małżonków ${ }^{38}$, zamiast pojawiać się tylko „od święta”.

Jak już zostało wskazane wyżej, najgłębszym wymiarem sposobu bycia w relacji z drugą osobą jest czynienie z siebie bezinteresownego daru. Postawa ta wpływa na rozwój osoby, a następnie na rozwój miłości. Jednak koniecznym uzupełnieniem jest fakt wzajemności owego daru. To znaczy, że powinien on dotyczyć obu współmałżonków. Co więcej, każdy dar powinien być «dawany», jak i «odbierany» ${ }^{39}$. Wiąże się to z gotowością do przyjmowania od drugiej osoby tego, czym chce obdarować.

W małżeństwie konkretnym aktem obdarowania sobą współmałżonka jest sam akt zaślubin. Z jednej strony mowa tu o akcie prawnym, na którego mocy mężczyzna i kobieta stają się małżeństwem. Następnie, poprzez wyrażoną zgo-

32 Można to wnioskować na podstawie całego nauczania św. Jana Pawła II, które mieści się w nurcie personalistycznym.

33 Por. K. Lubowicki, Duchowość małżeńska..., dz. cyt., s. 278, 281.

34 Por. FC 11; KKK 365.

35 Por. Jan Paweł II, Jesteście świadkami wewnętrznej prawdy miłości. Przemówienie do uczestników światowego zgromadzenia ruchu Focolari, poświęconego rodzinie i mitości, 3.05.1981, [w:] NP 4-1, s. 526, za: K. Lubowicki, Duchowość małżeńska..., s. 278.

36 Por. Jan Paweł II, Małżeństwo chrześcijańskie jest zaczynem postępu moralnego dla społeczeństwa. Homilia do rodzin w Kinszasie, 3.05.1980, za: K. Lubowicki, Duchowość matżeńska..., dz. cyt., s. 278.

$37 \quad$ K. Wojtyła, Rodzina jako..., dz. cyt., s. 353.

38 Por. Jan Paweł II, Do nowożeńców. Pozdrowienia podczas audiencji ogólnej, 30.05.1979, za: K. Lubowicki, Duchowość małżeńska..., dz. cyt., s. 279.

39 Por. K. Wojtyła, Rodzina jako..., dz. cyt., s. 354-355. 
dę, powstaje przymierze małżeńskie ${ }^{40}$. W wymiarze sakramentalnym małżeństwo tworzy nierozerwalną wspólnotę życia ${ }^{41}$.

Istotnym wymiarem communio personarum, obok opisanej wyżej wspólnoty życia małżonków, jest wspólnota dialogu. Przekłada się ona na znajdowanie przez małżonków czasu na rozmowę opartą na wzajemnym słuchaniu i akceptacji, a oprócz tego na szczerości i braku osądzania ${ }^{42}$. Ważna jest tutaj motywacja do podejmowania dialogu - urzeczywistnianie zamiaru Bożego wobec małżeństwa.

Papież nauczając o dialogu małżeńskim wskazuje na szczególną rolę przebaczenia. Powołując się na wzór Chrystusa, motywuje małżonków do darowania win współmałżonka. Św. Jan Paweł II dopomina się, by gniew, żal i chowane urazy nie były silniejsze od miłości i komunii małżeńskiej na co dzień. Stwierdza ponadto, że przebaczenie jest wyznacznikiem dojrzałości człowieka, jak i miłości ${ }^{43}$. Równocześnie zachęta do stałego przebaczania stanowi wyzwanie i szansę dla małżonków.

Życie według takich zasad w małżeństwie wymaga stałej pracy i rozwoju. Konieczne jest pogłębianie komunii między małżonkami. Możliwe jest to dzięki łasce sakramentu małżeństwa, w której udzielony Duch Święty uzdalnia ich do wzrastania w tej jedności oraz obdarowuje nową komunią i miłością ${ }^{44}$.

\section{Personalistyczne postrzeganie małżeństwa i rodziny - zastosowanie profilaktyczne}

Według Słownika współczesnego języka polskiego profilaktyka to „wszelkie działania podejmowane w celu zapobieżenia czemuś; obrona przed niepożądanym skutkiem czegos'" ${ }^{45}$. Z tego względu, ukazując praktyczny wymiar życia według postulatów personalistycznych, można się odwoływać do aspektu zapobiegania zagrożeniom współczesnej rodziny. Drogą do owego zapobiegania może być odpowiednie przygotowanie do małżeństwa, w którym podejmowany byłby temat communio personarum wraz $\mathrm{z}$ istotnym cechami małżeństwa (nierozerwalność, wierność). Nie bez znaczenia jest także sama postawa na-

$40 \quad$ Por. tamże, s. 356.

41 KKK 1610.

42 Por. Jan Paweł II, List do «Equipes Notre-Dame», 19.09.1997, za: K. Lubowicki, Duchowość małżeńska...,dz. cyt., s. 285.

43 Por. K. Lubowicki, Duchowość małżéska..., dz. cyt., s. 286.

44 FC 19.

45 Profilaktyka, [w:] Słownik współczesnego języka polskiego, red. B. Dunaj, Warszawa 1996, s. 855. 
rzeczonych, których otwartość i chęć urzeczywistniania prawdy o małżeństwie w ich życiu jest podstawą do jej realizowania. Następnie, stała formacja małżonków przez chociażby uczestnictwo w rekolekcjach małżeńskich, ale także codzienne praktykowanie komunii osób może utrwalać przedstawiany model.

Realizowanie i stałe pogłębianie personalistycznej wizji małżeństwa i rodziny chroni przed co najmniej kilkoma współczesnymi zagrożeniami. Bowiem przekonanie o nierozerwalnej jedności małżeństwa stanowi dla małżonków szansę na to, by zapobiec rozwodowi. Perspektywa ta jest szczególnie ważna przy pokonywaniu kryzysów, kiedy chęć wytrwania w komunii osób może stanowić motywację do przezwyciężania trudności. Z tego względu mowa tu o zapobieganiu dysfunkcji rodziny związanej z nieumiejętnością pokonywania kryzysów.

W zakresie komunikacji małżeńsko-rodzinnej poszanowanie godności osoby wymaga stosowania takich technik komunikacyjnych, które nie krzywdzą rozmówcy. Oprócz tego komunikacja może być wciąż usprawniana, ponieważ w dążeniu do jedności z małżonkiem w każdym obszarze życia naturalna jest otwartość na uczucia i myśli drugiej osoby, dążenie do zrozumienia oraz akceptacja odmienności partnera. Podczas rozwiązywania konfliktów obok umiejętności psychologicznych szczególnie ważna jest rola przebaczenia. Dzięki niemu możliwe jest przepracowywanie urazów i żalu do współmałżonka lub innej bliskiej osoby w rodzinie.

Światopogląd personalistyczny chroni tradycyjny model małżeństwa tworzonego przez kobietę i mężczyznę. Bowiem całkowita jedność, o której tu mowa, możliwa jest tylko w przypadku osób płciowo zróżnicowanych. Z kolei poczęcie i zrodzenie dzieci, które jest nieodłącznym elementem życia większości małżeństw, wiązać się będzie z uznaniem godności człowieka od samego poczęcia. Chroni to przed dokonywaniem aborcji oraz sztucznym sposobem przekazywania życia.

W kontekście pracy z rodziną personalistyczna wizja człowieka i rodziny ma niebagatelne znaczenie. Bowiem postrzeganie człowieka całościowo, z uwzględnieniem wszystkich obszarów jego funkcjonowania, może ułatwić dokonywanie oceny i diagnozy problemów, z którymi się on boryka. Co za tym idzie, może prowadzić do niesienia interdyscyplinarnej pomocy, która obejmie wszystkie obszary dotknięte trudnościami.

Podsumowując niniejsze rozważania: postrzeganie małżeństwa i rodziny w kategorii communio personarum stanowi szansę na głębokie przeżywanie więzi małżeńskiej. Ważnym sposobem na to jest częste prowadzenie dialogu małżeńskiego jednoczącego małżonków. Jak nauczał św. Jan Paweł II: „bez takiej «komunii osób» w rodzinie nie może być cywilizacji miłości”46. Z tego wzglę-

46 Jan Paweł II, List do rodzin Gratissimam sane, 13. 
du dbanie o rodzinę nie tylko wpływa na nią samą i jej najbliższe otoczenie, ale też ma znaczenie dla globalnego sposobu życia.

\section{Bibliografia}

Bartnik C. S., Personalizm, Lublin 2013.

Dec I., Personalizm, [w:] Powszechna encyklopedia filozofii, t. 8, red. A. Maryniarczyk, Lublin 2007.

Jan Paweł II, Adhortacja apostolska o zadaniach rodziny chrześcijańskiej w świecie współczesnym Familiaris consortio (22.11.1981).

Jan Paweł II, List apostolski Mulieris dignitatem o godności i powołaniu kobiety (15.08.1988).

Jan Paweł II, List do rodzin Gratissimam sane (2.02.1994).

Jan Paweł II, Mężczyzna i niewiastą stworzył ich, Watykan 1986.

Katechizm Kościoła katolickiego, Poznań 2009.

Kongregacja Nauki Wiary, Instrukcja „Dignitas personae” dotycząca niektórych problemów bioetycznych (12.12.2008).

Konstytucja duszpasterska o Kościele w świecie współczesnym Gaudium et spes (7.12.1965).

Kowalczyk S., Personalizm - podstawy, idee, konsekwencje, Lublin 2012.

Lubowicki K., Duchowość małżeńska w nauczaniu Jana Pawła II, Kraków 2012.

Ozorowski E., Obraz Boży, [w:] Człowiek, osoba, płeć, red. M. Wójcik, Łomianki 1998.

Pastwa A., Istotne elementy małżeństwa. W nurcie odnowy personalistycznej, Katowice 2007.

Pawłowska P., Kobiecość: wizja genderowa a perspektywa personalistyczna listu apostolskiego „Mulieris dignitatem” (praca magisterska), Katowice 2014.

Pismo Święte Starego i Nowego Testamentu. Biblia Tysiąclecia, Warszawa 2007.

Słownik współczesnego języka polskiego, red. B. Dunaj, Warszawa 1996.

Wojtyła K., Rodzina jako „communio personarum”. Próba interpretacji teologicznej, „Ateneum Kapłańskie" 66 (1974) t. 83 z. 3, s. 347-361. 
Uniwersytet Papieski

Té. Jana Pawła II

5.7. W Wrakowie 